\title{
Order Imbalances and Market Efficiency: Evidence from the Taiwan Stock Exchange
}

\author{
Yi-Tsung Lee* \\ Yu-Jane Liu* \\ Richard Roll ${ }^{* *}$ \\ Avanidhar Subrahmanyam **
}

February 5, 2003

\begin{tabular}{|c|c|c|c|c|}
\hline & Lee & Liu & Roll & Subrahmanyam \\
\hline Address & \multicolumn{2}{|c|}{$\begin{array}{c}\text { National Chengchi University } \\
\text { 64, Chi Nan Road., Sec. } 2 \\
\text { Mucha, Taipei } 11623 \\
\text { Taiwan, R.O.C. }\end{array}$} & \multicolumn{2}{|c|}{$\begin{array}{c}\text { The Anderson School at UCLA } \\
110 \text { Westwood Plaza } \\
\text { Los Angeles, CA 90095-1481 } \\
\text { U.S.A. } \\
\end{array}$} \\
\hline E-mail & Actyt1@nccu.edu.tw & Finyj1@nccu.edu.tw & rroll@Anderson.ucla.edu & subra@Anderson.ucla.edu \\
\hline Voice & \multicolumn{2}{|c|}{$886-2-2939-3091$} & $1-310-825-6118$ & $1-310-825-5355$ \\
\hline Fax & \multicolumn{2}{|c|}{ 886-2-2939-3394 } & $1-310-206-8404$ & $1-310-206-5455$ \\
\hline
\end{tabular}

We thank an anonymous JFQA referee, Jonathan Karpoff (the editor), and Michael Brennan for valuable comments. 


\title{
Order Imbalances and Market Efficiency: Evidence from the Taiwan Stock Exchange
}

\begin{abstract}
Data from the Taiwan Stock Exchange identify the originator of each submitted order, and there are no designated dealers or specialists. We study marketable order imbalances, i.e., the net order flow resulting from trades that demand immediacy. We distinguish imbalances by trader type (individuals, domestic institutions, foreign institutions) and by the usual size of each trader's order. Day-to-day persistence in order imbalance is strongest for small foreign institutions and weakest for large individual traders. Such persistence emanates both from splitting orders over time and from herding, and there is little evidence that aggregate price pressures from such persistence last beyond a trading day, indicating that de facto market making is quite effective. We attempt to discern which types of traders are de facto liquidity-providers, which are likely to be informed, and which trade for liquidity reasons. The evidence indicates that all trader classes are successful market makers, large domestic institutions conduct the most informed trades, and large individuals are noise or liquidity traders.
\end{abstract}




\section{Introduction}

Volume has been the traditional link between trading activity and stock market returns (e.g., see Benston and Hagerman, 1974; Gallant, Rossi, and Tauchen, 1992; Hiemstra and Jones, 1994; Lo and Wang, 2000; and also the studies summarized in Karpoff, 1987). However, recent studies (e.g., Chan and Fong, 2000, and Chordia, Roll, and Subrahmanyam, 2002) recognize that volume conceals important aspects of trading. Consider, for example, a reported volume of one million shares. This might be a million shares sold to a market maker or a million shares purchased. Perhaps more typically, it would be roughly split, about 500,000 shares sold to and 500,000 shares bought from the market maker. The large order imbalance in the former case should have a greater impact on price because it could signal private information (Kyle, 1985) and because it would exert pressure on market maker inventory, thereby prompting a change in quotes (Stoll, 1978).

Most existing studies analyze order imbalances around specific events or over short periods of time. Sias (1997) analyzes order imbalances in the context of institutional buying and selling of closed-end funds; Lauterbach and Ben-Zion (1993) and Blume, MacKinlay, and Terker, (1989) study order imbalances around the October 1987 crash; and Lee (1992) does the same around earnings announcements. Using data for about six months, Chan and Fong (2000) estimate how order imbalances change the contemporaneous relation between stock volatility and volume. Hasbrouck and Seppi (2001) and Brown, Walsh, and Yuen (1997) study order imbalances for thirty and twenty stocks, over one and two years, respectively. 
A long-term study using accurate order imbalances for a broad cross-section has not been performed primarily because transactions databases available in the U.S. do not identify buyers and sellers. The investigator is obliged to estimate whether each order is buyer-initiated or seller-initiated, a task unavoidably subject to at least some error. ${ }^{1}$ Further, previous studies of order imbalances have focused usually on aggregates over all traders. More finely categorized imbalances could reveal whether particular groups of individuals follow sophisticated strategies, others engage in market making or informed trading, and yet others behave as prototypical liquidity or noise traders.

Our available data include all orders submitted to the Taiwan Stock Exchange (henceforth, TWSE) from September 1996 to April 1999 inclusive. The accompanying information discloses whether an order is buyer- or seller-initiated and it also identifies the initiator. There are no officially designated market makers on the TWSE. To retain confidentiality, we classify traders into six groups: habitually large and small traders, and within each size category, as individuals, domestic institutions, or foreign institutions. (Almost all foreign traders are institutions; foreign individuals are virtually excluded by regulation from trading on the TWSE.)

We analyze the imbalances of orders that seek immediacy; i.e., "marketable" limit orders, defined as orders to sell at or below the lowest prevailing ask price or orders to buy at or above the highest prevailing bid price, in the likelihood that inventory pressures are exerted by and private information is encapsulated in such orders. Our approach aggregates marketable limit order imbalances within the trading day, then (1) differentiates the properties and determinants of

\footnotetext{
${ }^{1}$ Chordia, Roll, and Subrahmanyam (2001) study market-wide order imbalances on the NYSE over an eleven-year period. They use the Lee and Ready (1991) trade assignment algorithm.
} 
daily order imbalances by trader category, (2) investigates how daily individual stock returns are related to order imbalances of each category, (3) documents the price impact of each trader type, and (4) investigates the return performance of the six trader classes. The results shed light on the sources of day-to-day inventory pressures, the types of traders that countervail these pressures, the price impact of various trader classes, traders' relative propensity to act as de facto market makers, informed traders, or liquidity traders, and the profitability of orders submitted by different trader classes.

The paper is organized as follows: Section 2 describes the research issues our data have the potential to address; Section 3 describes the data and uncovers determinants of imbalances; Section 4 discusses the relation between returns and the order imbalances emanating from various types of traders; Section 5 examines the link between trader types and traditional market microstructure classifications; Section 6 examines the profitability of strategies employed by various trader groups; and Section 7 concludes. 


\section{Research Issues}

This section provides a brief review of the order imbalance literature and delineates the questions our data have the opportunity to address.

It is by now established that order imbalances are substantially and positively autocorrelated; see Chordia, Roll, and Subrahmanyam (2002) (CRS), even though daily returns exhibit very little serial dependence. Extant literature has yet to uncover the source of imbalance persistence, though CRS speculate that such autocorrelation can arise either because of herding (e.g., Scharfstein and Stein, 1990; Hirshleifer, Subrahmanyam, and Titman, 1994) or because traders split orders over time to reduce price impact (e.g., Kyle 1985). Our data have the potential to address which classes of agents cause autocorrelation in imbalances. Further, by looking at autocorrelations in imbalances when trades by the same agent are included and, in turn, excluded, we can address the role played by order splitting vis-à-vis herding-induced imbalance persistence.

Many researchers starting with Kraus and Stoll (1972) have documented price pressures caused by institutional traders. Theoretical models such as Ho and Stoll (1981) and Spiegel and Subrahmanyam (1995) predict long-lived price pressures caused by trading activity. We are able to examine which agent classes move prices the most, and to explore whether price pressures caused by agents endure beyond a trading day. By doing so, we gain a better understanding of how resilient markets are in accommodating trades, and which agents impose the greatest strains on resiliency. 
Finally, we can shed light on the market microstructure taxonomy of informed traders, liquidity traders, and market makers (e.g., Glosten and Milgrom, 1985). In an order-driven market like Taiwan, there are no designated market makers; so all agents are free to indulge in de facto market making. Glosten (1994) suggests that market making activity would tend to involve nonmarketable limit orders designed to capture the bid-ask spread, while informed and liquidity trading would demand immediacy and tend to be conducted by submitting marketable limit orders. The relative proportion of non-marketable and marketable limit orders submitted by each type of agent is a measure of the propensity to engage in de facto market making. Further, the return performance of such orders sheds light on whether agents are successful in this endeavor. The performance of marketable limit orders submitted by particular categories of agents allows us to deduce which classes are most often in possession of private information and which are more likely be liquidity or noise traders. 


\section{Imbalance Data}

\subsection{Trading Protocol and Data Description}

There are no designated dealers or specialists in Taiwan. Traders submit limit orders (specifying price, sign, and quantity). There are periodic call auctions on the exchange when the trade price is chosen by a computer to maximize accumulated order volume. The time between auctions averages 60-90 seconds depending on trading volume.

After each call auction, the highest unexecuted bid price and the lowest unexecuted ask price become the "prevailing" quotes, which we use to define a "marketable" order prior to the next auction. Any subsequent order to sell at or below the prevailing bid or buy at or above the prevailing ask is deemed marketable. However, not every marketable order is executed during the auction a minute or so later. For example, suppose the prevailing ask is 50 and the next lowest sell order in the book is 51 ; and then only two buy orders arrive before the next auction, one at 51 and another at 50\%2. Both buy orders would be "marketable" for our purposes, but only the buy order at 51 would be executed (crossed against the prevailing lowest sell order at 50.) The buy order at $50^{1 / 2}$ and the pre-existing sell order at 51 would become the new prevailing quotes after the next auction. We do not include unexecuted marketable orders in calculations involving successive imbalances.

On each trading day from September 1996 through April 1999, inclusive, we tabulated the buy and sell orders submitted (including the number of shares in lots of 1000 shares) for the thirty largest stocks on the Taiwan stock exchange (TWSE.) The submitter of each order was 
identified as a domestic individual, a domestic institution, or a foreign institution. ${ }^{2}$ Traders were further classified as "large" if they submitted orders larger than ten lots more than $50 \%$ of the time over the entire sample period, and "small" otherwise.

Three fates are possible for orders submitted to the TWSE: (1) the order is crossed with another, resulting in a transaction; (2) the order is cancelled by the originator; (3) the order is expunged automatically if it is still pending at the close of trading. An unexecuted order can, of course, be resubmitted on the following trading day.

For a given trader class, the daily order imbalance is calculated as all marketable buy orders less marketable sell orders, ${ }^{3}$ not including any that were cancelled during the day or expunged at close of trading. The imbalance is reported either in number of orders or in number of shares. Marketable limit orders are used because they demand immediacy, and we seek to understand the impact of such trades on the price formation process.

To report the results more succinctly, from this point order imbalances, liquidity, and trading activity are value-weighted averages over all thirty stocks based on market capitalization at the end of the preceding month.

\footnotetext{
${ }^{2}$ There were too few trades by foreign individuals to form a meaningful category. They were not included in the sample.

${ }^{3}$ Recall that a "marketable" order is one submitted at the best prevailing bid or ask quote.
} 


\subsection{Summary Statistics}

Table 1 presents descriptive statistics for average order imbalances. The total share order imbalance measures have negative means and medians. Returns in Taiwan have been negative over the sample period. The table shows that all domestic traders who demanded immediacy were net sellers during the sample period regardless of category. However, foreign institutional traders, particularly small ones, were buyers.

Table 2 reports autocorrelations for order imbalances and daily returns on a value-weighted portfolio of the sample stocks. Six lags comprise a calendar week, since the TWSE was open Monday through Saturday for most of our sample period. ${ }^{4}$ In contrast to returns, most order imbalance autocorrelations are positive and many are statistically significant.

Foreign institutional traders display more autocorrelation in orders than other traders. For order imbalances in shares, the first-order autocorrelation displayed by large individual traders is small and mostly insignificant, a feature shared by neither domestic and foreign institutions nor small individual traders. Among small traders, autocorrelations are generally positive for individuals as well as institutions.

From this point, we report results only for imbalances computed in shares (lots); imbalances computed using number of orders give virtually identical results.

\footnotetext{
${ }^{4}$ The TWSE was open Monday through Saturday up to December 1998. From January 1998 up to the end of our sample period the exchange followed an alternating system of a five-day week followed by a six-day week. The exchange switched to a five-day week in January 2001.
} 


\subsection{Evidence on the Sources of Persistence in Imbalance}

An issue raised by the evidence of persistence is whether it arises from herding by different agents or splitting of orders over time by the same agent. Theoretical literature suggests both possibilities. For example, reputational considerations could cause institutions to herd (Scharfstein and Stein, 1990). Intertemporal herding is also predicted by the model of Hirshleifer, Subrahmanyam, and Titman (1994), where agents receive private information sequentially. Finally, well-known price formation models such as Kyle (1985) imply that privately informed agents would split their orders over time to minimize the overall price impact of their trading activity. We now shed some light on these alternative explanations of persistence in imbalances.

Panel A of Table 3 presents own autocorrelations with and without deleting the trades of the same traders on successive days. This provides a perspective on whether autocorrelations are positive because of herding or splitting orders. Not surprisingly, the autocorrelation estimates are smaller after trades by the same agent are deleted. However, large individuals do not exhibit any evidence of imbalance autocorrelation in either case. In addition, the coefficients become insignificant for large foreign institutions and small individuals after the deletion, implying that autocorrelation in imbalances for these agent classes arises from order splitting. The coefficients for small foreign institutions are significantly smaller after the deletion, but remain significantly positive implying that both herding and splitting of orders are important in causing imbalance persistence for this class of agents. 
While the point estimates indicate that a substantial portion of imbalance persistence for domestic institutions arise from herding as well as splitting, the difference in the estimates with and without deletion of the same trader is not statistically significant. This suggests that herding is the predominant cause of imbalance persistence for domestic institutions.

Overall, we find much larger point estimates of autocorrelations for institutions relative to individuals, and also that the orders of domestic institutions are predominantly caused by herding. These findings are consistent with the notions that domestic institutions are more likely to have a reputational motive for herding (Scharfstein and Stein, 1990), and also are more likely to trade on private information (Hirshleifer, Subrahmanyam, and Titman, 1994). The lower persistence of imbalances exhibited by individuals suggests they have no reputational reason to herd, and are unlikely to possess private information on a regular basis. We will shed more light on these issues below when we tabulate the profitability of trades conducted by the various classes of agents.

\subsection{Predictors of Imbalance}

We next attempt to discern predictors of imbalances across different classes of agents. Our objective is to ascertain the extent to which traders follow strategies that naïvely depend on past returns (e.g., Barberis, Shleifer, and Vishny, 1998, or Odean, 1998). To this end, a forecasting regression using past market returns, day-of-the-week indicator variables, and lagged order imbalances is reported in Table 4. To make the coefficients easier to compare across trader classes, all variables are scaled by the average absolute imbalance level of the class. 
There is evidence of momentum trading two days after up-market moves and contrarian trading two days after down-market moves. This evidence is consistent with the slight momentum in upmarket moves and the slight reversal after down-market moves documented in Chordia, Roll, and Subrahmanyam (2002), though the gap of a day is surprising. We also find that there is a tendency for more selling activity to occur on Tuesdays than on other days. Overall, while these results are intriguing, their significance is debatable in light of the fact that the explanatory power of the regressions is below $10 \%$ in every case except that of small foreign institutions. However, even in this case, the already documented serial correlation in imbalance appears to drive the bulk of the explanatory power (the square of the first order serial correlation for small foreign institutions approaches $31 \%$, which is close to the $\mathrm{R}^{2}$ of $36 \%$ for this agent class). Overall, we conclude that agents, on aggregate, do not exhibit compelling evidence of strategies that naively extrapolate from past price trends. 


\section{Market Returns and Imbalances Across Trader Types}

Empirical studies of block trading dating back to Kraus and Stoll (1972) find that institutional trades exert pressure on prices. The analysis of Chordia and Subrahmanyam (2002) indicates that persistence in imbalance could cause continuing price pressures in the direction of an initial imbalance shock. This section provides further empirical information about this phenomenon by estimating the directional impact on future market returns of the order imbalances generated by different trader types.

To allow for a differential impact of excess buy and sell orders, we split imbalances into positive and negative parts and include them as separate regressors. $\mathrm{EBO}_{\mathrm{t}}$ is defined as $\max \left[0, \mathrm{OIB}_{\mathrm{t}}\right]$ while $\mathrm{ESO}_{\mathrm{t}}=-\min \left[0, \mathrm{OIB}_{\mathrm{t}}\right]$ where $\mathrm{OIB}_{\mathrm{t}}$ is the buy-sell order imbalance $\mathrm{t}$ days prior to the observation date; $(\mathrm{t}=0,1$.

Table 5 presents a pure forecasting regression of returns on lagged imbalances. In terms of explanatory power, the forecasting ability of lagged imbalances is weak to nonexistent. Nonetheless, yesterday's positive share purchase imbalances of small domestic and foreign institutions are significantly related to today's return, as is yesterday's selling imbalance for large domestic institutions. Thus, some price pressure seems to persist beyond a single day, though, as the R-squares reveal, the materiality is marginal at best. In addition, negative imbalances are reversed, but positive imbalances continue. The reversals following selling activity are consistent with Cox and Peterson (1994), who document that stock returns reverse after large declines. The reversal is also consistent with standard models of inventory such as Grossman and Miller (1988). The continuing pressures caused by small foreign and domestic institutions 
are consistent with the large autocorrelations in their demands (Table 2) and with the analysis of Chordia and Subrahmanyam (2002), who demonstrate analytically that there is a positive predictive relation between trader demands and future returns when market makers with inventory concerns face autocorrelated imbalances.

Overall, we conclude that the ability of the exchange to accommodate imbalances is quite strong since the evidence of continuing price pressures caused by marketable limit imbalances is not very compelling. In the next section, we further study the provision of market making services, and discuss whether any class of agents is more or less likely to indulge in de facto market making activity. 


\section{Trader Classification and the Taxonomy of Market Microstructure}

Market microstructure paradigms typically separate agents into market makers, informed traders, and liquidity traders. Without officially designated market makers, any trader could assume the different roles of traditional microstructure taxonomy. To address whether any trader class in Taiwan is more apt to assume a particular role, we provide two pieces of evidence. First, we document the average price impact of an individual order submitted by each trader type. This should indicate the efficacy of agents' trading strategies in reducing trading costs. Second, we conjecture that traders acting as market makers would have a greater propensity to place limit orders that do not demand immediacy, while informed and liquidity traders would demand immediacy and submit more frequent marketable limit orders, i.e., orders that are placed at the prevailing inside bid price (for a sell) and ask price (for a buy). We therefore provide the crosscorrelation between marketable and non-marketable orders, as well as the proportion of nonmarketable orders submitted by each trader type.

Table 6 provides evidence on the price impact of each trader type. Returns across call auctions are regressed on the signed imbalance (in monetary terms) submitted by each trader type between auctions; separate regressions for each trader type pool all orders submitted by that type in all stocks. ${ }^{5}$

\footnotetext{
${ }^{5}$ Using order-to-order price impact data, (returns regressed on each order separately, without pooling between auctions), gives similar results except that the price impact of large domestic institutions is insignificant. These results are based on calculations performed on each stock separately and then averaged across stocks. We also performed daily multivariate regressions of returns on the imbalances of different trader classes and found substantively similar results. We did not report these because the coefficients are influenced by daily frequency of trading, and we wished to discern the price impact on a trade-by-trade basis.
} 
In general, the price impact coefficients for marketable orders are all significant and positive, implying that all classes of agents play significant roles in moving prices. Small foreign institutions have the largest price impact coefficient, followed by small individuals and large foreign institutions. The estimated price impacts of these trader groups significantly exceed those of domestic institutions and large individual traders (Panel B). Strategic models of price formation (e.g., Glosten, 1989 and Kyle, 1985) suggest that astute informed traders can obtain profits by designing strategies to minimize price impact; we will explore in Section 7 whether agents with low price impact are able to obtain substantially higher trading profits relative to those with high price impact.

Non-marketable orders have a negative price impact suggesting that all classes lean against the wind on occasion and provide liquidity to the market. Again, small foreign institutions lead the way followed by larger foreign institutions. Large Domestic institutions rank third in this activity.

The importance of marketable limit orders can be measured by the difference in price impact coefficients relative to those of non-marketable limit orders. For each trader category, this difference is reported in Panel C of Table 6. In every case, it is very large and significant, thereby supporting our focus on marketable limit orders as important drivers of price movements and of non-marketable limit orders as measures of liquidity.

Table 7 provides daily cross-correlations between marketable and non-marketable orders. This reveals the identity of traders who are absorbing orders demanding immediacy. Liquidity 
appears to be provided predominantly by small individuals as their non-marketable orders are consistently negatively correlated with that of other traders, indicating that these agents often "lean against the wind." Large domestic institutions also play an important role in absorbing the marketable orders, as evidenced by the fact that four out of the six correlations corresponding to this class of agents are significantly negative.

The proportion of marketable limit orders submitted by each trader type is reported in Table 8 . This is a proxy for the frequency of demand for immediacy. Consistent with Table 7, the results reveal that foreign institutions have the most frequent demand for immediacy, while the less frequent demands for immediacy of both domestic institutions and individuals are of similar magnitude. Foreign institutions are urgent more than fifty percent of the time while domestic institutions and individuals seek immediacy less than half the time; all these proportions are significantly different from one-half.

Evidently, a larger portion of trading by domestic institutions and individuals involves nonmarketable limit orders, which suggests that these groups act frequently as de facto market makers. The larger demand for immediacy by foreign traders is consistent with their more frequent liquidity needs and/or their possession of private information.

Overall, the evidence suggests that some categories of traders are more likely to be perceived as informed while other classes are more prone to act as market makers. The next section documents the profits of these groups. This should shed some light on whether de facto market making is actually profitable relative to information-based trading. 


\section{Trading Profits.}

Do various trading strategies generate materially different profits? An answer is provided in Table 9, which reports profits by trader category. Each submitted order is tracked until it is completely offset by another order, and returns are measured across these events. These returns are separated into non-marketable limit orders (Panel A-1) and marketable limit orders (Panel A2.) Panel A-3 of Table 9 reports the differential profit between non-marketable and marketable orders. All trader classes submit profitable non-marketable orders (Panel A-1 of Table 9) based on mean returns; however, the median small foreign institution submits unprofitable ones.

Domestic institutions, small individuals, and small foreign institutions have consistently positive mean returns for marketable orders (Panel A-2). However, the marketable limit orders submitted by large individuals are not profitable, whereas the marketable orders submitted by the median small foreign institution are not profitable.

Overall, the evidence indicates that all classes except small foreign institutions indulge in successful de facto market making by submitting non-marketable limit orders. Domestic institutions submit profitable marketable limit orders and fit the profile of privately informed agents. It is also worth noting that the price impact of domestic institutions is smaller than any other class (Table 6). This indicates that domestic institutions are able to strategically trade in a manner that allows them to profit on their information while minimizing their price impact. The finding accords with models in which informed traders trade strategically over time to minimize their price impact (Kyle, 1985). 
On average, the marketable limit orders of small foreign institutions are also profitable, though the median such institution does not perform well on its marketable limit orders. This indicates that some small foreign institutions often possess private information, but the median institution does not. The marketable limit orders of large individuals and large foreign institutions perform poorly, suggesting that these agents often trade as noise or liquidity traders. 


\section{Conclusion}

The relations between trading activity and liquidity and between trading activity and market returns have been explored extensively in previous literature. Trading activity has usually been measured by volume, but the inventory paradigm, (developed, for example, in Stoll, 1978, and Spiegel and Subrahmanyam, 1995) and recent empirical work (Chordia, Roll, and Subrahmanyam, 2002) suggests that imbalance between buyer- and seller-initiated orders should be a powerful determinant of liquidity and price movement beyond volume per se. Going beyond that finding, this paper explores imbalances across different trader classes that trade on the Taiwan Stock Exchange (TWSE). The TWSE does not have designated market makers, indicating that agents have an incentive to indulge in de facto market making activity to absorb the imbalances of traders that demand immediacy (Glosten, 1994)

Our analysis provides information on questions such as: (1) Which agents tend to cause day-today price pressures? (2) Whose orders move prices the most? (2) Which agents are more likely to act as de facto market makers when there are no designated dealers or specialists? (4) Are the activities of de facto market makers profitable? (5) Which agents exhibit the strongest evidence of informed trading and which exhibit the strongest evidence of liquidity or noise trading?

We find that domestic and foreign institutions have more persistent order imbalances than large individual traders. Hence, institutions appear to induce continuations in price pressures. Both herding and splitting orders appear to cause such persistence, consistent with the herding models 
of Scharfstein and Stein (1990) and Hirshleifer, Subrahmanyam, and Titman (1994), and with models based on Kyle (1985), in which agents split orders over time to minimize their price impact. The marketable limit orders of large individual investors perform poorly, indicating that such agents often act as liquidity or noise traders. However, marketable orders submitted by domestic institutions are profitable with low price impact, indicating the possession of private information, on which they trade strategically to minimize price impact.

The non-marketable orders of all categories of agents are profitable, suggesting that market making activity is successfully undertaken even when there are no designated market makers. Indeed, even without designated market makers, the exchange is quite effective in absorbing order imbalances, as there is little compelling evidence that price pressures created by these imbalances persist beyond a trading day. Overall, our study contributes to our understanding of the sources of persistence in imbalances, as well as the efficacy and profitability of liquidity provision in markets without designated dealers. 


\section{References}

Atkins, A., and E. Dyl, 1990, Price reversals, bid-ask spreads, and market efficiency, Journal of Financial and Quantitative Analysis 25, 535-547.

Benston, G., and R. Hagerman, 1974, Determinants of bid-asked spreads in the over-the-counter market, Journal of Financial Economics 1, 353-364.

Blume, M., A. MacKinlay, and B. Terker, 1989, Order imbalances and stock price movements on October 19 and 20, 1987, Journal of Finance 44, 827-848.

Judge, George G., W. E. Griffiths, R. Carter Hill, Helmut Lütkepohl, and Tsoung-Chao Lee, 1985, The Theory and Practice of Econometrics, (New York: Wiley).

Brown, P., D., Walsh, and A. Yuen, 1997, The interaction between order imbalance and stock price, Pacific-Basin Finance Journal 5, 539-557.

Chan, K., and W. Fong, 2000, Trade size, order imbalance, and the volatility-volume relation, Journal of Financial Economics 57, 247-273.

Christie, W., and Schultz, P., 1999, The initiation and withdrawal of odd-eighth quotes among Nasdaq stocks: An empirical analysis, Journal of Financial Economics 52, 409-442.

Chordia, T., R. Roll, and A. Subrahmanyam, 2002, Order imbalance, liquidity, and market returns, Journal of Financial Economics 65, 111-130.

Chordia, T., and A. Subrahmanyam, 2002, Order imbalance and individual stock returns, working paper, Emory University.

Cox, D., and D. Peterson, 1994, Stock returns following large one-day declines: Evidence on short-term reversals and longer-term performance, Journal of Finance 49, 255-267.

Gallant, A., P. Rossi, and G. Tauchen, 1992, Stock prices and volume, Review of Financial Studies 5, 199-242.

Gibbons, M., and P. Hess, 1981, Day of the week effects and asset returns, Journal of Business 54, 579-596.

Glosten, L., 1994, Is the electronic open limit order book inevitable?, Journal of Finance 49, 1127-1161.

Glosten, L., and P. Milgrom, 1985, Bid, ask and transaction prices in a specialist market with heterogeneously informed traders, Journal of Financial Economics 14, 71-100. 
Hasbrouck, J., and D. Seppi, 2001, Common factors in prices, order flows and liquidity, Journal of Financial Economics 59, 383-411.

Hiemstra, C., and J. Jones, 1994, Testing for linear and nonlinear Granger causality in the stock price-volume relation, Journal of Finance 49, 1639-1664.

Hirshleifer, D., A. Subrahmanyam, and S. Titman, 1994, Security analysis and trading patterns when some investors receive information before others, Journal of Finance 49, 1665-1698.

Ho, T., and H. Stoll, 1981, Optimal dealer pricing under transaction and return uncertainty, Journal of Financial Economics 9, 47-73.

Ho, T., and H. Stoll, 1983, The dynamics of dealer markets under competition, Journal of Finance 38, 1053-1074.

Jones, C., G. Kaul, and M. Lipson, 1994, Transactions, volume, and volatility, Review of Financial Studies 7, 631-651.

Karpoff, J., 1987, The relation between price changes and trading volume: A survey, Journal of Financial and Quantitative Analysis 22, 109-125.

Kraus, A., and H. Stoll, 1972, Parallel trading by institutional traders, Journal of Financial and Quantitative Analysis 7, 2107-2138.

Kyle, A., 1985, Continuous auctions and insider trading, Econometrica 53, 1315-1335.

Lauterbach, B., and U. Ben-Zion, 1993, Stock market crashes and the performance of circuit breakers: Empirical evidence, Journal of Finance 48, 1909-1925.

Lee, C., 1992, Earnings news and small traders: An intraday analysis, Journal of Accounting and Economics 15, 265-302.

Lee, C., and B. Radhakrishna, 2000, Inferring trader behavior: Evidence from TORQ data, Journal of Financial Markets 3, 83-111.

Lee, C., and M. Ready, 1991, Inferring trade direction from intraday data, Journal of Finance 46, 733-747.

Ljung, G., and G. Box, 1978, On a measure of lack of fit in time-series models, Biometrika 75, 355-361.

Lo A., and J. Wang, 2000, Trading volume: definitions, data analysis, and implications of portfolio theory, Review of Financial Studies 13, 257-300.

Odders-White, Elizabeth R., 2000, On the occurrence and consequences of inaccurate trade classification, Journal of Financial Markets 3, 205-332. 
Scharfstein, D., and J. Stein, 1990, Herd behavior and investment, American Economic Review $80,465-479$.

Shleifer, A., 1986, Do demand curves for stocks slope down?, Journal of Finance 41, 579-590.

Sias, R., 1997, Price pressure and the role of institutional traders in closed-end funds, Journal of Financial Research 20, 211-229.

Spiegel, M., and A. Subrahmanyam, 1995, On intraday risk premia, Journal of Finance 50, 319339.

Stoll, H., 1978, The supply of dealer services in securities markets, Journal of Finance 33, 1133-1151. 


\section{Table 1. Order Imbalance Descriptive Statistics.}

Daily marketable limit order imbalances on the TWSE (Taiwan Stock Exchange) were computed from September 1996 through April 1999 inclusive, 703 days, for the thirty largest stocks. Order imbalance was defined as buy orders less sell orders during the day (using marketable limit orders). Imbalances were tabulated separately for individuals, domestic and foreign institutions. In addition, traders were classified as large or small by tracing their order sizes during the entire sample period. A large trader had to place orders of at least ten lots more than $50 \%$ of the time. Summary measures are obtained by averaging individual stocks using market capitalization weights from the end of the previous calendar month. Means, medians, and standard deviations (STD) are computed over the entire sample.

\begin{tabular}{|c|c|c|c|c|c|c|c|c|}
\hline & Total & Individuals & $\begin{array}{c}\text { Domestic } \\
\text { Institutions }\end{array}$ & $\begin{array}{c}\text { Foreign } \\
\text { Institutions }\end{array}$ & Total & Individuals & $\begin{array}{c}\text { Domestic } \\
\text { Institutions }\end{array}$ & $\begin{array}{c}\text { Foreign } \\
\text { Institutions }\end{array}$ \\
\hline & \multicolumn{4}{|c|}{ Large Traders } & \multicolumn{4}{|c|}{ Small Traders } \\
\hline & \multicolumn{8}{|c|}{ Number of orders } \\
\hline Mean & -24 & -22 & -2 & 0 & -63 & -66 & -3 & 6 \\
\hline Median & -28 & -26 & -2 & 0 & -64 & -66 & -2 & 1 \\
\hline \multirow[t]{2}{*}{ STD } & 89 & 86 & 4 & 2 & 376 & 388 & 4 & 27 \\
\hline & \multicolumn{8}{|c|}{ Shares (lots) } \\
\hline Mean & -554 & -458 & -99 & 3 & -417 & -349 & -104 & 36 \\
\hline Median & -697 & -561 & -118 & -2 & -420 & -342 & -105 & 0 \\
\hline STD & 3120 & 2780 & 448 & 109 & 1215 & 891 & 427 & 622 \\
\hline
\end{tabular}


Table 2. Serial Correlation of Returns and Order Imbalances.

Serial correlations (up to six lags) were computed for order imbalances and daily returns. Daily order imbalances on the TWSE (Taiwan Stock Exchange) were computed from September 1996 through April 1999 inclusive, 703 days, for the thirty largest stocks. Order imbalance was defined as buy orders less sell orders during the day (using marketable limit orders). Imbalances were tabulated separately for individuals, domestic and foreign institutions. In addition, traders were classified as large or small by tracing their order sizes during the entire sample period. A large trader had to place orders of at least ten lots more than $50 \%$ of the time. Summary measures are obtained by averaging individual stock coefficients using market capitalization weights from the end of the previous calendar month. Significance levels of $0.1,0.05$ and 0.01 are indicated by *,** and ***, respectively. The Ljung and Box (1978) Q test is for the null hypothesis that all six coefficients are zero.

Lag
(Days) $\quad$ Total $\quad$ Individuals $\begin{gathered}\text { Domestic } \\ \text { Institutions Institutions }\end{gathered} \quad$ Total Individuals $\begin{gathered}\text { Domestic } \\ \text { Institutions Institutions }\end{gathered}$

\begin{tabular}{|c|c|c|c|c|c|c|c|c|c|}
\hline & \multicolumn{4}{|c|}{ Large Traders } & \multicolumn{4}{|c|}{ Small Traders } & \multirow[b]{2}{*}{ Returns } \\
\hline & \multicolumn{8}{|c|}{ Number of Orders } & \\
\hline 1 & 0.040 & 0.041 & $0.176 * * *$ & $0.126^{* * * *}$ & $0.331 * * *$ & $0.355 * * *$ & $0.265 * * *$ & $0.542 * * *$ & 0.041 \\
\hline 2 & $0.076^{* *}$ & $0.081 * *$ & 0.050 & $0.166 * * *$ & $0.156 * * *$ & $0.178 * * *$ & $0.106 * * *$ & $0.527 * * *$ & 0.005 \\
\hline 3 & $0.129 * * *$ & $0.138 * * *$ & 0.020 & $0.108 * * *$ & $0.181 * * *$ & $0.199 * * *$ & -0.023 & $0.438 * * *$ & 0.045 \\
\hline 4 & 0.013 & 0.022 & -0.057 & 0.047 & $0.105 * * *$ & $0.123 * * *$ & 0.022 & $0.437 * * *$ & $-.0670 *$ \\
\hline 5 & $0.101 * * *$ & $0.106 * * *$ & -0.026 & $0.086 * *$ & 0.042 & 0.057 & -0.001 & $0.365^{* * *}$ & -0.041 \\
\hline 6 & $0.080 * *$ & $0.083 * *$ & -0.014 & 0.030 & 0.052 & $0.070 *$ & -0.056 & $0.372 * * *$ & \multirow[t]{10}{*}{0.018} \\
\hline Q test & $28 * * *$ & $32 * * *$ & $25 * * *$ & $46^{* * *}$ & $127 * * *$ & $154 * * *$ & $59 * * *$ & $860 * * *$ & \\
\hline \multicolumn{9}{|c|}{ Shares (Lots) } & \\
\hline 1 & 0.046 & 0.025 & $0.197 * * *$ & $0.089 * *$ & $0.152 * * *$ & $0.085 * *$ & $0.213 * * *$ & $0.557 * * *$ & \\
\hline 2 & 0.053 & $0.064^{*}$ & 0.044 & $0.074^{*}$ & $0.074 *$ & 0.027 & $0.127 * * *$ & $0.426^{* * *}$ & \\
\hline 3 & 0.024 & 0.031 & 0.035 & 0.027 & $0.099 * * *$ & $0.133 * * *$ & $0.070 *$ & $0.351 * * *$ & \\
\hline 4 & -0.055 & -0.049 & -0.010 & -0.007 & 0.051 & 0.023 & $0.072 *$ & $0.323 * * *$ & \\
\hline 5 & 0.009 & 0.013 & 0.025 & $0.082 * *$ & 0.053 & 0.035 & 0.035 & $0.246^{* * *}$ & \\
\hline 6 & 0.014 & 0.013 & 0.058 & -0.012 & 0.060 & -0.007 & 0.059 & $0.239 * * *$ & \\
\hline Q test & 6 & 5 & $30 * * *$ & $14 * *$ & $33 * * *$ & $19 * * *$ & $53 * * *$ & $586^{* * *}$ & \\
\hline
\end{tabular}




\section{Table 3: The Sources of Persistence In Imbalances}

Daily order imbalances (OIB) on the Taiwan Stock Exchange were computed as in Table 1. Panel A below provides comparisons of daily autocorrelations with and without trades by the same traders. Panel B tests if these autocorrelations are significantly different from zero. Significance of $0.1,0.05$ and 0.01 are indicated by $* * *$ and $* * *$, respectively.

Panel A. Autocorrelations (one-day lag),

OIB in shares including and excluding the same traders on day $t$ and day $t-1$

\begin{tabular}{lccc|ccc}
\hline & \multicolumn{3}{c|}{ Large } & \multicolumn{3}{c}{ Small } \\
\cline { 2 - 7 } & \multicolumn{2}{c}{ Individuals $\begin{array}{c}\text { Domestic } \\
\text { Institutions }\end{array}$} & $\begin{array}{c}\text { Foreign } \\
\text { Institutions }\end{array}$ & Individuals & $\begin{array}{c}\text { Domestic } \\
\text { Institutions Institutions }\end{array}$ & $\begin{array}{c}\text { Foreign } \\
\text { Including same traders }\end{array}$ \\
\cline { 2 - 8 } Excluding same traders & 0.025 & $0.197 * * *$ & $0.089 * *$ & $0.085 * *$ & $0.213 * * *$ & $0.557 * * *$ \\
\cline { 2 - 7 } & 0.029 & $0.123 * * *$ & -0.008 & -0.030 & $0.134 * * *$ & $0.355^{* * *}$
\end{tabular}

Panel B. Wald tests for the difference between own OIB autocorrelations with and without the same traders on day $\mathrm{t}$ and day $\mathrm{t}-1$

\begin{tabular}{|c|c|c|c|c|c|c|}
\hline & \multicolumn{3}{|c|}{ Large } & \multicolumn{3}{|c|}{ Small } \\
\hline & Individuals & $\begin{array}{l}\text { Domesti } \\
\text { Institutiol }\end{array}$ & $\begin{array}{c}\text { Foreign } \\
\text { Institutions }\end{array}$ & Individuals & $\begin{array}{l}\text { Domest } \\
\text { Institutio }\end{array}$ & $\begin{array}{l}\text { Foreign } \\
\text { Institutions }\end{array}$ \\
\hline $\mathrm{F}$ & 0.07 & 1.02 & 2.86 & 4.11 & 1.62 & 16.54 \\
\hline$p$-value & 0.791 & 0.313 & 0.091 & 0.043 & 0.203 & 0.000 \\
\hline
\end{tabular}


Table 4. Determinants of Order Imbalances.

Daily order imbalances by trader category, as described in Tables 1 and 2, are regressed here on day-of-the-week dummies, lagged imbalances of the same trader category, and past positive and negative market returns. Since the TWSE trades on Saturday, six lags and dummies span one week. $\mathrm{WD}_{\mathrm{j}}$ is a day-of-the-week dummy with Saturday as the base case, (i.e., $\mathrm{j}=1, \ldots, 5$ denotes Monday,...,Friday.) The order imbalance $\left(\mathrm{OIB}_{\mathrm{t}}\right)$ is in shares (lots) and is value-weighted across the thirty largest stocks $t$ days prior to the observation date. All OIB variables are scaled by the average absolute imbalance level of the class. $\operatorname{MAXR}_{t}=\max \left(0, R_{t}\right)$ and $\operatorname{MINR}_{t}=\min \left(0, R_{t}\right)$ where $R_{t}$ is the valueweighted average return for the thirty stocks $t$ days prior to the observation date. Value weights are based on market capitalization at the end of the previous month. Significance levels of $0.1,0.05$ and 0.01 are denoted by *, ** and ***, respectively. The R-square is adjusted for degrees of freedom.

\begin{tabular}{|c|c|c|c|c|c|c|c|c|}
\hline \multirow[b]{3}{*}{ Intercept } & Total & Individuals & $\begin{array}{c}\text { Domestic } \\
\text { Institutions }\end{array}$ & $\begin{array}{l}\text { Foreign } \\
\text { Institutions }\end{array}$ & Total & Individuals & $\begin{array}{c}\text { Domestic } \\
\text { Institutions }\end{array}$ & $\begin{array}{c}\text { Foreign } \\
\text { Institutions }\end{array}$ \\
\hline & \multicolumn{4}{|c|}{ Large } & \multicolumn{4}{|c|}{ Small } \\
\hline & -11.7 & -6.87 & -28.0 & 19.2 & $-40.3 * *$ & -18.5 & $-56.2 * * *$ & -22.6 \\
\hline $\mathrm{WD}_{1}$ & $-35.2 *$ & $-37.9 * *$ & -7.16 & -24.2 & -2.29 & -17.3 & 9.88 & 12.7 \\
\hline $\mathrm{WD}_{2}$ & $-51.7 * * *$ & $-51.2 * * *$ & $-39.7 * *$ & $-51.0^{*}$ & $-35.4^{*}$ & $-38.7 * *$ & -26.5 & -0.101 \\
\hline $\mathrm{WD}_{3}$ & -13.9 & -12.0 & -19.9 & -32.2 & 3.93 & -15.3 & -9.62 & $38.8^{* *}$ \\
\hline $\mathrm{WD}_{4}$ & -22.7 & -23.9 & -2.84 & -50.2 & -9.87 & -19.6 & -6.80 & 7.74 \\
\hline $\mathrm{WD}_{5}$ & -12.6 & -14.2 & -3.37 & 9.73 & 1.55 & -9.03 & 1.92 & 14.8 \\
\hline $\mathrm{OIB}_{1}$ & 0.002 & 0.001 & $0.057 * * *$ & 0.116 & $0.014 * * *$ & $0.020 * * *$ & $0.054 * * *$ & $0.110 * * *$ \\
\hline $\mathrm{OIB}_{2}$ & 0.002 & 0.004 & -0.005 & 0.111 & 0.002 & 0.000 & 0.023 & $0.027 * *$ \\
\hline $\mathrm{OIB}_{3}$ & 0.000 & 0.001 & 0.018 & 0.031 & $0.009^{*}$ & $0.020 * * *$ & 0.022 & 0.010 \\
\hline $\mathrm{OIB}_{4}$ & -0.000 & -0.001 & 0.015 & -0.052 & 0.009 & 0.005 & 0.020 & $0.034 * * *$ \\
\hline $\mathrm{OIB}_{5}$ & 0.000 & 0.001 & 0.003 & $0.195^{* *}$ & 0.001 & -0.002 & -0.003 & -0.006 \\
\hline $\mathrm{OIB}_{6}$ & 0.004 & 0.004 & 0.016 & -0.058 & 0.008 & -0.001 & 0.010 & 0.015 \\
\hline $\mathrm{MAXR}_{1}$ & 0.716 & 1.61 & -3.40 & 10.6 & 7.40 & $-11.1 * *$ & $29.3^{* * *}$ & 7.12 \\
\hline $\mathrm{MAXR}_{2}$ & $16.0^{* *}$ & $13.1^{*}$ & $16.6^{* * *}$ & 1.52 & $11.5^{*}$ & 3.78 & 2.05 & $11.2^{*}$ \\
\hline $\mathrm{MAXR}_{3}$ & 6.20 & 5.37 & 1.35 & 2.38 & 6.79 & -3.63 & 7.05 & $10.7^{*}$ \\
\hline $\mathrm{MAXR}_{4}$ & -6.72 & -6.90 & -6.56 & -0.0612 & $-14.4^{* *}$ & -9.06 & -6.22 & $-16.8 * * *$ \\
\hline $\mathrm{MAXR}_{5}$ & -5.24 & -5.67 & -4.16 & -2.96 & 6.29 & $11.47 * *$ & -3.19 & -2.85 \\
\hline $\mathrm{MAXR}_{6}$ & -5.57 & -6.38 & 0.312 & 10.4 & -5.58 & -6.71 & 1.61 & 2.65 \\
\hline $\mathrm{MINR}_{1}$ & -2.61 & -3.25 & 3.48 & 5.02 & -2.31 & -7.40 & -9.43 & 6.34 \\
\hline $\mathrm{MINR}_{2}$ & $-13.8^{* *}$ & $-15.6^{* *}$ & $-13.5^{* *}$ & 6.86 & -8.41 & -6.23 & -0.308 & $-12.1 * *$ \\
\hline $\mathrm{MINR}_{3}$ & 0.783 & 0.767 & -6.04 & 5.84 & -4.01 & -4.48 & $-16.0 * *$ & 1.73 \\
\hline $\mathrm{MINR}_{4}$ & 0.105 & 1.79 & $-13.8^{* *}$ & 6.99 & 2.14 & 2.28 & -8.95 & 8.23 \\
\hline $\mathrm{MINR}_{5}$ & 4.46 & 4.65 & 3.31 & -3.12 & 1.19 & -1.81 & 7.69 & -3.36 \\
\hline $\mathrm{MINR}_{6}$ & -11.1 & -11.1 & -6.11 & -16.9 & -7.51 & -2.81 & -0.358 & -8.58 \\
\hline R-Square & 0.016 & 0.015 & 0.061 & 0.009 & 0.042 & 0.032 & 0.084 & 0.355 \\
\hline
\end{tabular}




\section{Table 5. Determinants of Returns.}

The dependent variable is the daily value-weighted average return, $\mathrm{R}_{\mathrm{t}}$, for the thirty largest stocks on the Taiwan Stock Exchange. Explanatory variables include lagged positive and negative daily order imbalances and lagged positive and negative value-weighted average returns. Separate regressions are presented using the order imbalances of large and small traders. Traders were classified as large or small by tracing their order sizes during the entire sample period. A large trader had to place orders of at least ten lots more than $50 \%$ of the time. Order imbalances (OIB) are in shares (lots); and are value-weighted daily averages. $\mathrm{EBO}_{1}=\max \left(0, \mathrm{OIB}_{1}\right)$ and $\mathrm{ESO}_{1}=-$ $\min \left(0, \mathrm{OIB}_{1}\right)$ one day prior to the observation date. Similarly, $\mathrm{MAXR}_{1}=\max \left(0, \mathrm{R}_{1}\right)$ and $\mathrm{MINR}_{1}=\min \left(0, \mathrm{R}_{1}\right)$. To make the coefficients more readable, $R_{t}$ is multiplied by 10,000. Significance levels of $0.1,0.05$ and 0.01 are denoted by $*, * *$, and ${ }^{* *}$, respectively. The R-square is adjusted for degrees of freedom.

\begin{tabular}{|c|c|c|c|c|c|c|c|c|}
\hline & Total & Individuals & $\begin{array}{l}\text { Domestic } \\
\text { Institutions }\end{array}$ & $\begin{array}{c}\text { Foreign } \\
\text { Institutions }\end{array}$ & Total & Individuals & $\begin{array}{l}\text { Domestic } \\
\text { Institutions }\end{array}$ & $\begin{array}{c}\text { Foreign } \\
\text { Institutions }\end{array}$ \\
\hline & \multicolumn{4}{|c|}{ Large Traders } & \multicolumn{4}{|c|}{ Small Traders } \\
\hline Intercept & -2.41 & 40.2 & -1250 & -702. & -433. & -1048. & -811 & -670. \\
\hline $\mathrm{EBO}_{1}$ & 0.044 & 0.067 & 3.97 & 9.25 & $1.69 *$ & 1.13 & $5.64 * * *$ & $2.94 * *$ \\
\hline $\mathrm{ESO}_{1}$ & 0.338 & 0.451 & $-4.40 *$ & -16.3 & -0.104 & -1.68 & -1.83 & 0.592 \\
\hline $\mathrm{MINR}_{1}$ & -0.081 & -0.089 & 0.01 & -0.013 & -0.030 & 0.01 & -0.024 & -0.045 \\
\hline $\mathrm{MAXR}_{1}$ & 0.093 & 0.089 & 0.09 & 0.094 & 0.063 & 0.10 & 0.077 & 0.080 \\
\hline R-Square & -0.001 & -0.001 & 0.00 & 0.003 & 0.002 & 0.00 & 0.008 & 0.005 \\
\hline
\end{tabular}




\section{Table 6. Price Impact of trades}

The proportional price change from one call auction to the next is regressed on the total signed dollar accumulated order size between auctions, for each class of trader. Separate regressions for each trader type pool all orders submitted by that type in all stocks. Panel A presents the basic regression results, while Panel B tests for differences in the coefficients across trader types using an F-test. Significance at the $0.1,0.05$ and 0.01 level is indicated by $* * *$ and $* * *$, respectively.

Panel A: Price Impact Coefficients

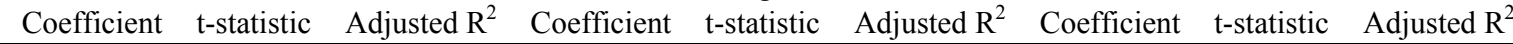
Individuals $\quad$ Domestic Institutions $\quad$ Foreign Institutions

Marketable limit orders

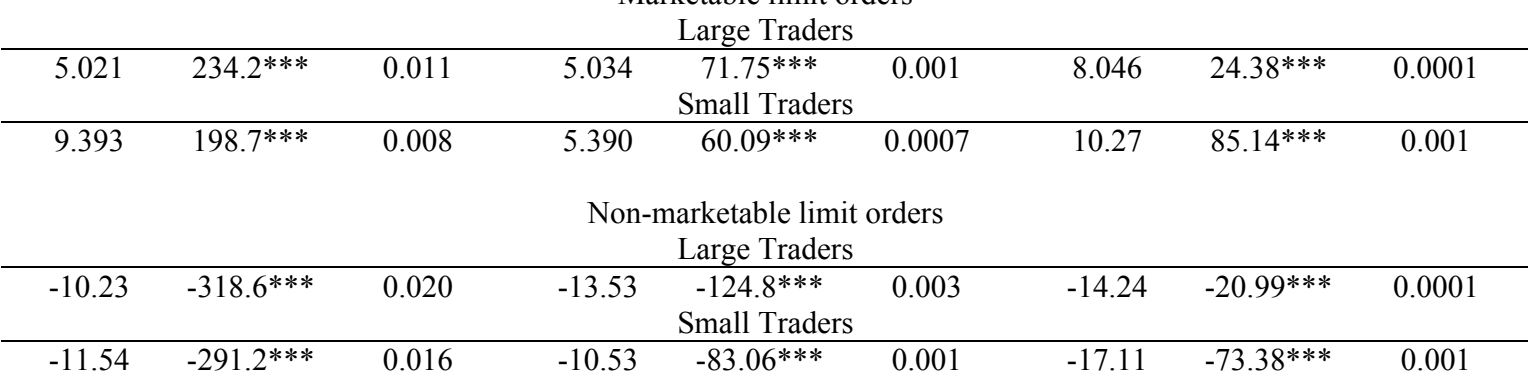

Panel B: Differences in Price Impact across trader types (Column less Row Coefficient)

\begin{tabular}{ccccc} 
& Large Traders & \multicolumn{2}{c}{ Small Traders } \\
\hline Individuals & $\begin{array}{c}\text { Domestic } \\
\text { Institutions }\end{array}$ & $\begin{array}{c}\text { Foreign } \\
\text { Institutions }\end{array}$ & Individuals & $\begin{array}{c}\text { Domestic } \\
\text { Institutions }\end{array}$
\end{tabular}

Marketable limit orders

\begin{tabular}{|c|c|c|c|c|c|c|}
\hline \multirow{2}{*}{$\begin{array}{l}\text { Large } \\
\text { Traders }\end{array}$} & $\begin{array}{c}\text { Domestic } \\
\text { Institutions }\end{array}$ & -0.013 & & & & \\
\hline & $\begin{array}{c}\text { Foreign } \\
\text { Institutions }\end{array}$ & $-3.025 * * *$ & $-3.012 * * *$ & & & \\
\hline \multirow{3}{*}{$\begin{array}{c}\text { Small } \\
\text { Traders }\end{array}$} & Individuals & $-4.372 * * *$ & $-4.359 * * *$ & $-1.347 * * *$ & & \\
\hline & $\begin{array}{c}\text { Foreign } \\
\text { Institutions }\end{array}$ & $-5.247 * * *$ & $-5.234 * * *$ & $-2.222 * * *$ & $-0.875 * * *$ & $-4.878 * * *$ \\
\hline & \multicolumn{5}{|c|}{ Non-marketable limit orders } & \\
\hline $\begin{array}{l}\text { Large } \\
\text { Traders }\end{array}$ & $\begin{array}{c}\text { Domestic } \\
\text { Institutions }\end{array}$ & $3.298 * * *$ & & & & \\
\hline \multirow{3}{*}{$\begin{array}{l}\text { Small } \\
\text { Traders }\end{array}$} & Individuals & $1.311 * * *$ & $-1.987 * * *$ & $-2.703 * * *$ & & \\
\hline & $\begin{array}{c}\text { Domestic } \\
\text { Institutions }\end{array}$ & $0.301 * *$ & $-2.997 * * *$ & $-3.713 * * *$ & $-1.01 * * *$ & \\
\hline & $\begin{array}{c}\text { Foreign } \\
\text { Institutions }\end{array}$ & $6.877 * * *$ & $3.579 * * *$ & $2.863 * * *$ & $5.566 * * *$ & $6.576^{* * *}$ \\
\hline
\end{tabular}

Panel C: Difference in price impact between marketable and non-marketable orders in Panel A

\begin{tabular}{cccccc}
\multicolumn{2}{c}{ Large Traders } & \multicolumn{3}{c}{ Small Traders } \\
\hline Individuals & $\begin{array}{c}\text { Domestic } \\
\text { Institutions }\end{array}$ & $\begin{array}{c}\text { Foreign } \\
\text { Institutions }\end{array}$ & Individuals & $\begin{array}{c}\text { Domestic } \\
\text { Institutions }\end{array}$ & $\begin{array}{c}\text { Foreign } \\
\text { Institutions }\end{array}$ \\
\hline $15.25^{* * *}$ & $18.56^{* * *}$ & $22.29^{* * *}$ & $20.93^{* * *}$ & $15.92^{* * *}$ & $27.37 * * *$
\end{tabular}


Table 7. Contemporaneous correlations between marketable and non-marketable limit orders.

Daily cross-correlations were computed for marketable and non-marketable limit orders. Marketable limit orders are defined as orders placed at the prevailing inside quotes; i.e., sell orders placed at or below the highest prevailing bid or buy orders placed at or above the lowest prevailing offer. The number of marketable limit orders as a percentage of all orders is reported below for each trader category. Significance levels of $0.1,0.05$ and 0.01 are indicated by $*{ }^{* *}$ and $* * *$, respectively.

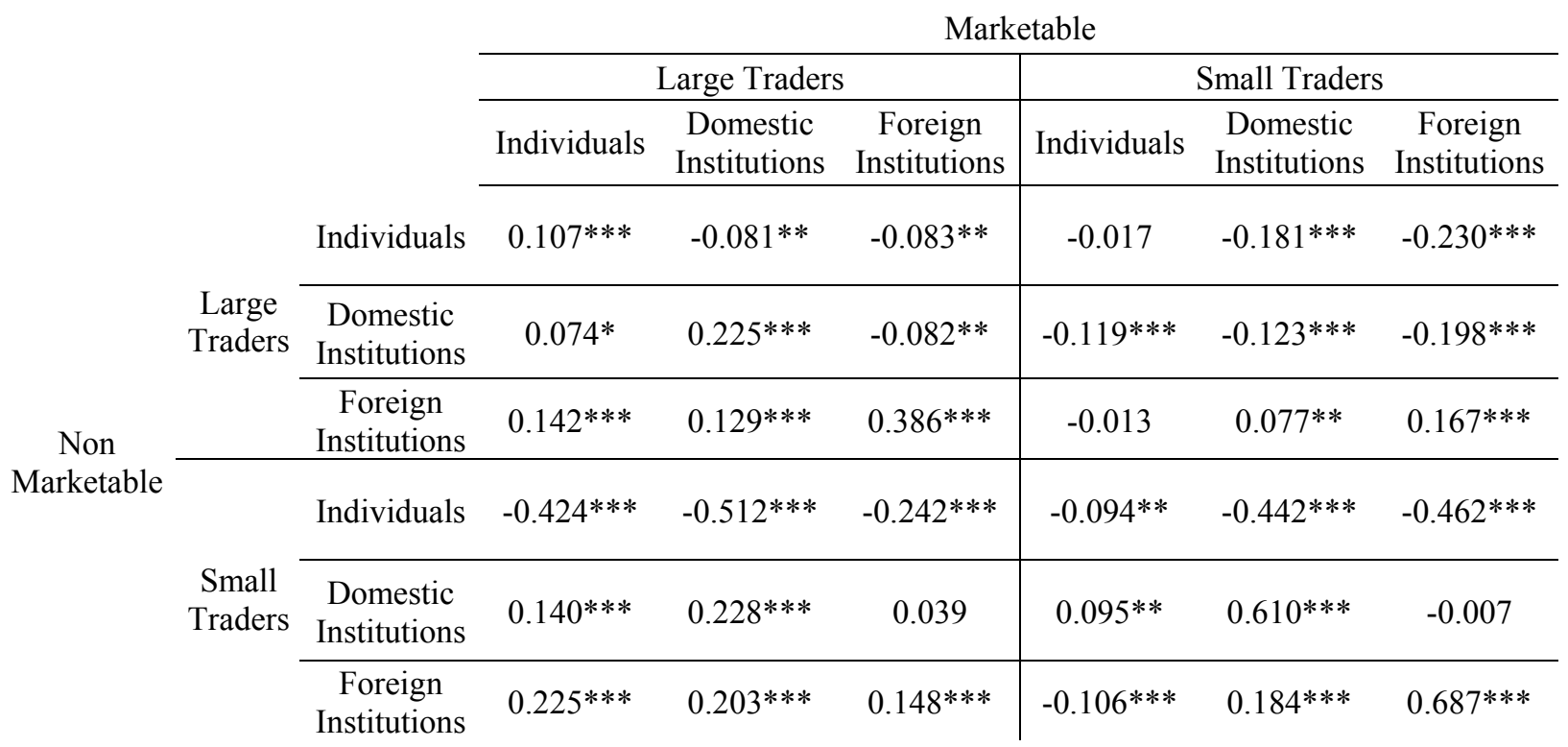




\section{Table 8. Proportion of Marketable Limit Orders}

Marketable limit orders are defined as orders placed at the prevailing inside quotes; i.e., sell orders placed at or below the highest prevailing bid or buy orders placed at or above the lowest prevailing offer. The number of marketable limit orders as a percentage of all orders is reported below for each trader category. Significance levels of $0.1,0.05$ and 0.01 are indicated by $* * *$ and $* * *$, respectively, for a test of the hypothesis that the relevant proportion is significantly different from 0.5 .

\begin{tabular}{cccccc}
\multicolumn{2}{c}{ Individuals } & \multicolumn{2}{c}{ Domestic Institutions } & \multicolumn{2}{c}{ Foreign Institutions } \\
\hline Large & Small & Large & Small & Large & Small \\
\hline \multicolumn{4}{c}{ Percentage of Number of Marketable Orders } \\
\hline $45.1^{* * *}$ & $42.0^{* * *}$ & $39.4^{* * *}$ & $42.9^{* * *}$ & $65.3^{* * *}$ & $71.8^{* * *}$ \\
\hline \multicolumn{4}{c}{ Percentage of Marketable Orders in Shares (Lots) } \\
\hline $42.7^{* * *}$ & $42.2^{* * *}$ & $39.3^{* * *}$ & $37.9^{* * *}$ & $54.9^{* *}$ & $56.1^{* * *}$
\end{tabular}


Table 9. Trading Profits by Trader Category.

Realized profits, defined as 100 [net sales revenue/gross purchase cost-1], were tabulated from executed orders involving the thirty largest stocks. Profits were calculated only for shares acquired by open market purchase or equity offering within the sample period. A sale was excluded if there was no recorded purchase prior to the sale date. Similarly, purchases still held at the end of the sample were excluded. Separate transactions initiated by the same order were aggregated. Profits are net of expenses, which on the TWSE include a commission of $0.1425 \%$ for each trade and a transaction tax of $0.3 \%$ on the gross dollar amount of each sale. Adjustments are made for all stock dividends; (there are no splits in Taiwan.) Cash dividends are included in gross revenue without discounting or reinvestment. Panel A gives profits by category. Means and median returns were calculated from trader returns pooled across all stocks. ${ }^{6}$ Tests for medians are based on signed rank tests. Significance levels of $0.1,0.05$ and 0.01 are indicated by *,** and $* * *$, respectively.
Large
Small
Large
Small
Large
Small
Individuals
Domestic Institutions
Foreign Institutions

Panel A-1. Average Returns by Category For Non-Marketable Orders

Pooled Trader Mean Return

\begin{tabular}{|c|c|c|c|c|c|}
\hline $3.016^{* * *}$ & $3.612 * * *$ & $4.250^{* * *}$ & $4.782 * * *$ & $6.698 * * *$ & $6.584 * * *$ \\
\hline \multicolumn{6}{|c|}{ Pooled Trader Median Return } \\
\hline $1.783 * * *$ & $2.383 * * *$ & $2.475 * * *$ & $2.203 * * *$ & $1.675 * * *$ & -2.534 \\
\hline \multicolumn{6}{|c|}{ Panel A-2. Average Returns by Category For Marketable Orders } \\
\hline \multicolumn{6}{|c|}{ Pooled Trader Mean Return } \\
\hline$-0.024 * *$ & $0.305 * * *$ & $2.171 * * *$ & $2.601 * * *$ & 0.801 & $3.214 * * *$ \\
\hline \multicolumn{6}{|c|}{ Pooled Trader Median Return } \\
\hline$-0.180 * * *$ & $0.078 * * *$ & $0.884 * * *$ & $0.266^{* *}$ & $-1.465^{* * *}$ & $-3.331 * * *$ \\
\hline
\end{tabular}

Panel A-3. Difference of Average Returns between Non-Marketable Orders and Marketable Orders Pooled Trader Mean Return (t-test)

\begin{tabular}{cccccc}
\hline $3.040^{* * *}$ & $3.307^{* * *}$ & $2.079^{* * *}$ & $2.181^{* * *}$ & $5.897^{* * *}$ & $3.370^{* * *}$ \\
\hline \multicolumn{5}{c}{ Pooled Trader Median } & Return (Wilcoxon test) \\
\hline $1.963^{* * *}$ & $2.306^{* * *}$ & $1.591^{* * *}$ & $1.937^{* * *}$ & $3.141^{* * *}$ & $0.798^{* *}$
\end{tabular}

${ }^{6}$ For example, let $\mathrm{R}_{\mathrm{j}, \mathrm{k}}$ denote the return (\%) earned by trader $\mathrm{j}$ in stock $\mathrm{k}$ and let $\mathrm{N}_{\mathrm{k}}$ denote the number of traders of a given type for stock $k,(k=1, \ldots, 30$.$) Then the Mean of Individual Stock Means is \frac{1}{30} \sum_{k=1}^{30} \frac{1}{N_{k}} \sum_{j=1}^{N_{k}} R_{j, k}$ while the Pooled Trader Mean Return is $\frac{1}{30 \sum_{\mathrm{k}} \mathrm{N}_{\mathrm{k}}} \sum_{\mathrm{k}=1}^{30} \sum_{\mathrm{j}=1}^{\mathrm{N}_{\mathrm{k}}} \mathrm{R}_{\mathrm{j}, \mathrm{k}}$. There can be a difference when the number of traders differs across stocks. 